\title{
Use of enteral electrolyte solutions with different sodium acetate concentrations in weaned foals: the effects on acid-base balance, blood glucose, lactate, and urine ph
}

\author{
Lorena Chaves Monteiro ${ }^{1^{*}}$ (D) Rinaldo Batista Viana ${ }^{2}$ (i) Raffaella Bertoni Cavalcanti Teixeira $^{1}$ (iD) \\ Marcel Ferreira Bastos Avanza ${ }^{1}$ (i) Pedro Ancelmo Nunes Ermita ${ }^{3}$ (i) Caio Monteiro Costa ${ }^{1}$ (i) \\ Samuel Rodrigues Alves ${ }^{1}$ (i) Paulo Vinícius de Morais Santos ${ }^{1}$ (D) Daniel Atila de Barros Balbino ${ }^{1}$ (D) \\ João Paulo Albuquerque dos $\operatorname{Santos}^{4}$ (D) Leticia Faria de Morais ${ }^{5}$ (D) \\ Gabriella Maria Morais Ferreira ${ }^{1}$ Lorraine Marcele Lopes da $\operatorname{Costa}^{1}$ (1) \\ Felipe Sperandio de Mattos $^{5}$ José Dantas Ribeiro Filho ${ }^{1}$ (i)
}

${ }^{1}$ Laboratório de Pesquisa em Medicina Interna Veterinária, Departamento de Veterinária, Universidade Federal de Viçosa (UFV), 36570-000,
Viçosa, MG, Brasil. E-mail: lorenacmonteirovet@gmail.com. *Corresponding author.
${ }^{2}$ Instituto da Saúde e Produção Animal, Universidade Federal Rural da Amazônia (ISPA/UFRA), Belém, PA, Brazil.
${ }^{3}$ Instituto de Estudo dos Trópicos Úmidos, Universidade Federal do Sul e Sudeste do Pará, Xinguara, PA, Brasil.
${ }^{4}$ Departamento de Ciência Animal, Universidade Federal Rural da Região do Semi-árido (UFERSA), Mossoró, RN, Brasil.
${ }^{5}$ Centro Universitário de Viçosa (UNIVIÇOSA), Departamento de Veterinária, Viçosa, MG, Brasil.

ABSTRACT: The effects of acetate as an alkalinizing agent in maintenance enteral electrolyte solutions administered by nasogastric route in a continuous flow have not been previously described in weaned foals. This is the second part of a study that evaluated the effects of two electrolyte solutions of enteral therapy fluid in weaned foals. In this part, will be considered the effects of enteral electrolyte solutions containing different acetate concentrations on acid-base balance, blood glucose, lactate and urine pH of weaned foals. This was a controlled trial in a cross-over design performed in six foals with a mean age of $7.3 \pm 1.4$ months. After $12 \mathrm{~h}$ of water and food deprivation, each animal received the following two treatments by nasogastric route in a continuous flow of $15 \mathrm{ml} / \mathrm{kg} / \mathrm{h}$ during $12 \mathrm{~h}$ : HighAcetate (acetate $52 \mathrm{mmol} / \mathrm{l}$ ) and LowAcetate (acetate $22.6 \mathrm{mmol} / \mathrm{l})$. The HighAcetate treatment was effective in generating a slight increase in blood pH, blood bicarbonate concentration, base excess and urinary $\mathrm{pH}$.

Key words: fluid therapy, alkalinizer, horses, dehydration, metabolic acidosis.

Utilização de soluções eletrolíticas enterais com diferentes concentrações de acetato em potros desmamados: efeitos sobre o equilíbrio ácido base, concentrações plasmáticas de glicose e lactato e $\mathrm{pH}$ urinário

RESUMO: Os efeitos da utilização de acetato como um agente alcalinizante em soluções eletrolíticas enterais de manutenção administradas por sonda nasogástrica em fluxo contínuo não foram descritos em potros desmamados. O presente estudo teve como objetivo avaliar os efeitos de soluções eletroliticas enterais contendo diferentes concentrações de acetato sobre o equilibrio ácido base, concentrações plasmáticas de glicose e lactato, e pH urinário de potros desmamados. Este trabalho foi um estudo controlado em um delineamento cross-over (6X2) utilizando seis potros com idade média de $7.3 \pm 1.4$ meses. Após $12 \mathrm{~h}$ de restrição hídrica e alimentar, cada animal recebeu os dois tratamentos por via nasogástrica em fluxo contínuo de $15 \mathrm{ml} / \mathrm{kg} / \mathrm{h}$ durante $12 \mathrm{~h}$ : HighAcetate (52 mmol/l) e LowAcetate (22.6 mmol/l). O grupo HighAcetate foi eficaz em gerar um pequeno aumento no pH sanguíneo, concentração de bicarbonato sanguíneo, excesso de base e pH urinário. Palavras-chave: Hidratação, alcalinizante, equinos, desidratação, acidose metabólica.

\section{INTRODUCTION}

Foals with colitis and diarrhea often develop acid-base imbalances with metabolic acidosis being the most prevalent disorder (GOMEZ et al., 2013; GOMEZ; et al., 2015; KOTERBA; et al., 1984). The correction of hydro electrolytic and acid-base imbalances can be achieved through fluid therapy with crystalloid solutions administered by the parenteral or enteral route. The intravenous route enables a fast plasma volume expansion desirable in cases of severe dehydration and acid-base disbalance but requires the use of commercially available sterile solutions. In patients with mild to moderate dehydration and base acid imbalances, and normal function of the gastrointestinal tract, enteral hydration is an effective 
alternative to intravenous fluid therapy (AVANZA et al., 2009; RIBEIRO FILHO et al., 2014, 2017b). In some cases, the parenteral commercial electrolytic solutions do not have the appropriate composition to correct certain electrolytic and acid-base imbalances. Enteral electrolyte solutions can be precisely adjusted in their composition according to the electrolyte requirements of patients. Thus, enteral hydration may be a more appropriate option for certain pathological conditions.

Enteral fluid therapy has been shown to be effective in correcting electrolyte and acid-base imbalances, expand blood volume and increase renal perfusion without causing iatrogenic disorders in adult horses, cattle, buffalo calves, calves (AVANZA et al., 2009; ERMITA et al., 2016; RIBEIRO FILHO et al., 2013, 2017a, 2017b) and humans (BAHL; et al, 1996; RAUTANEN; et al, 1997; WORLD HEALTH ORGANIZATION, 2006).

The use of enteral solutions containing sodium acetate can be an alternative to sodium bicarbonate for the correction of acidosis in sick foals. Sodium acetate metabolism generates the consumption of hydrogen ions in the liver and muscle, without interfering with the $\mathrm{pH}$ of the intestinal lumen, making it more suitable for enteral electrolyte solutions compared to sodium bicarbonate (MARSHALL et al., 2008) in calves and horses with acidosis (NAYLOR\& FORSYTH, 1986; PETHICK et al., 1993; SEN et al., 2009; WALLER\& LINDINGER, 2007; WALLER et al., 2009).

The effects of enteral fluid therapy on acidbase balance in foals are still unknown. There are no scientific studies reporting the effects of enteral electrolyte solutions containing sodium acetate as an alkalinizing base in foals younger than one-year-old. This is the second part of a study that evaluated the effects of two electrolyte solutions of enteral therapy fluid in weaned foals (Monteiro et. al, 2020). In this part, the objective was to evaluate the effect of enteral electrolyte solutions, with different concentrations of sodium acetate, administered in a continuous flow by nasogastric route, on acid-base balance, blood glucose, lactate, and urinary $\mathrm{pH}$ in weaned foals. We hypothesized that the enteral electrolyte solutions containing higher concentration of acetate (HighAcetate - $52 \mathrm{mmol} / \mathrm{l}$ ) will have a higher alkalinizing effect in comparison to the enteral electrolyte solutions containing lower concentration of acetate (LowAcetate $-22 \mathrm{mmol} / l$ ).

\section{MATERIALS AND METHODS}

\section{Animals}

Six healthy Mangalarga Marchador foals, five male and one female, with a mean age of $7.3 \pm$
1.4 months and mean body weight of $165 \pm 24.4 \mathrm{~kg}$ were used in this study. All animals were considered healthy based on clinical examination and laboratory results (blood cell count and chemistry profile). The foals were kept in a paddock, fed concentrate pellet with $15 \%$ protein ( $1 \%$ body weight) and supplied with Tyfton 85 hay, water and mineral supplement ad libitum.

\section{Treatments and experimental design}

The concentration of acetate in the enteral electrolyte solutions was determined based on studies carried out in calves, calves and adult horses (PATRA et al., 1982; SEN et al., 2009; WALLER et al., 2009). In addition, the determination of acetate concentrations in this study was determined based on the results of pilot studies carried out previously.

Two electrolyte solutions with the following composition were tested: High Acetate Enteral Electrolyte Solution (HighAcetate - 52 $\mathrm{mmol} / l): 4 \mathrm{~g} / l$ sodium chloride; $0.5 \mathrm{~g} / l$ potassium chloride, $0.3 \mathrm{~g} / \mathrm{l}$ magnesium chloride hexahydrate, $2 \mathrm{~g} / \mathrm{l}$ calcium acetate monohydrate, $4 \mathrm{~g} / \mathrm{l}$ sodium acetate trihydrate and $10 \mathrm{~g} / \mathrm{l}$ dextrose, with a measured osmolarity of $289 \mathrm{mOsm} / \mathrm{l}$; Low Acetate Enteral Electrolyte Solution (LowAcetate - 22.6 $\mathrm{mmol} / \mathrm{l}): 4 \mathrm{~g} / l$ sodium chloride; $0.5 \mathrm{~g} / l$ potassium chloride, $0.3 \mathrm{~g} / \mathrm{l}$ magnesium chloride hexahydrate, 2 $\mathrm{g} / \mathrm{l}$ calcium acetate monohydrate and $10 \mathrm{~g} / \mathrm{l}$ dextrose, with a measured osmolarity of $225 \mathrm{mOsm} / \mathrm{l}$. The concentrations of each electrolyte $(\mathrm{mmol} / \mathrm{l})$, in both treatments, are demonstrated in table 1.

The animals were randomly assigned into treatment groups in a cross-over design $(6 \times 2)$. All animals received both treatments with a sevenday interval between them. During the experimental period they were kept in stalls (4 x 4 meters) with rubber mats to avoid bedding ingestion. Before the start of fluid therapy, the animals were fasted (food and water) for 12 hours. After the fasting period, a nasogastric tube was placed $(5 \mathrm{~mm}$ of internal diameter x $6 \mathrm{~mm}$ of external diameter x $1.5 \mathrm{~m}$ long). The tube was attached to the halter and connected to the enteral fluid therapy system, consisting of a reservoir with a 20-liter capacity connected to a 5-meter-long polyurethane coil infusion set with a drip chamber and a flow regulator.

Both treatments were administered for 12 hours. The flow of administration of enteral electrolyte solutions was $15 \mathrm{ml} / \mathrm{kg} / \mathrm{h}$ and was based on human medicine (RAUTANEN; et al, 1997), veterinary medicine (ERMITA et al., 2016; ERMITA et al., 2018; DANTAS et al., 2019) clinical trials, and the clinical routine of the authors. At the 
Table 1 - Components of enteral electrolyte solutions administered in continuous flow in foals with $52 \mathrm{mmol} / \mathrm{l}$ of acetate (HighAcetate) and $22.6 \mathrm{mmol} / l$ (LowAcetate).

\begin{tabular}{lcc}
\hline Treatments & HighAcetate & LowAcetate \\
\hline Sodium $(\mathrm{mmol} / l)$ & 107 & 73 \\
Potassium $(\mathrm{mmol} / l)$ & $6 . .5$ & 6.5 \\
Chloride $(\mathrm{mmol} / l)$ & 89.3 & 89.3 \\
Calcium $(\mathrm{mmol} / l)$ & 4.34 & 4.34 \\
Magnesium $(\mathrm{mmol} / l)$ & 1.16 & 1.16 \\
Acetate $(\mathrm{mmol} / l)$ & 52 & 22.6 \\
Glucose $(\mathrm{mmol} / l)$ & 55.5 & 55.5 \\
Measured Osmolarity $(\mathrm{mOsm} / l)$ & 289 & 225 \\
SID $(\mathrm{mmol} / l)$ & 24.2 & -9.8 \\
\hline
\end{tabular}

end of the fluid therapy the foals were released in a paddock where they received concentrate (at $0.5 \%$ body weight), Tifton 85 hay, water and mineral supplementation ad libitum.

\section{Sampling}

Laboratory evaluations were performed at the beginning of the fasting phase (T-12h), at the starting of the fluid therapy phase (T0h), at 4 hours (T4h), 8 hours (T8h), at the end of fluid therapy (T12h) and 12 hours after the fluid therapy was discontinued (T24h). Blood samples were collected via jugular venipuncture in syringes with lithium heparin (16 UI/ mL blood; S-Monovett - Sardtedt, Nümbrecht, Germany) to measure blood $\mathrm{pH}$, blood bicarbonate concentration $\left(\mathrm{HCO}_{3}^{-}\right)$, base excess (BE) and carbon dioxide partial pressure $\left(\mathrm{pCO}_{2}\right)$ using a portable blood gas analyzer (Cobas b 121, Roche Diagnóstica Ltda., Brazil). Blood samples were collected with a vacuum system in tubes containing sodium fluoride and EDTA $\mathrm{K}_{2}$ to measure glucose (Glucose Oxidase, Bioclin Quibasa, Minas Gerais, Brazil) and lactate concentration (UV Enzymatic by Dehydrogenase Lactate, Bioclin Quibasa, Minas Gerais, Brazil).

Urine samples were collected by spontaneous micturition and urinary $\mathrm{pH}$ was measured using a portable $\mathrm{pH}$ meter (Portable pH meter K39-0014P, Kasvi, Brazil), the authors remained with the animals throughout the fluid therapy phase to collect these materials. In each urination, all the volume of urine produced was collected in buckets previously cleaned with distilled water and dried. Results were grouped as follows: $\mathrm{T}-12 \mathrm{~h}$ (urine obtained from a single urination immediately before the onset of food and water deprivation); $\mathrm{T} 0-2 \mathrm{~h}$ (all the urine produced in the first two hours of fluid therapy); T2-6h (all urine produced between 2 and 6 hours of fluid therapy); T6$10 \mathrm{~h}$ (all urine produced between 6 and 10 hours of fluid therapy); T10-12h (all urine produced between 10 and 12 hours of fluid therapy); and T24h (urine obtained from a single urination 12 hours after the end of fluid therapy). Urinary $\mathrm{pH}$ was measured in all obtained samples, immediately after collected.

\section{Statistical analysis}

Data were subjected to descriptive analysis to obtain means and standard deviations. The normality of the data distribution and the sphericity of the variances were evaluated with Shapiro-Wilk and Mauchly tests, respectively. The main effects of time, treatments, and interaction time ${ }^{*}$ treatment were evaluated with an ANOVA based on a factorial planning of repeated measures. When necessary, a post hoc test of Least Significant Difference (LSD) was used to determine significance. For the variables that did not meet the ANOVA assumptions, the time effect was evaluated with a Kruskal-Wallis nonparametric test followed by Dunn's post hoc test, and the effect of the treatment at each time was evaluated with a Wilcoxon's test. All analyses were performed with the SPSS 25 (IBM, SPSS, Chicago, USA) statistical package, and $\mathrm{P}$ values $<0.05$ were considered significant.

\section{RESULTS}

All animals received both treatments. At each time, six samples of each treatment were obtained. The results expressed in table 2 are the average values of all samples $(n=6)$ obtained at each time for each treatment. Blood gas parameters, glucose and lactate findings are described in table 2 , and urinary $\mathrm{pH}$ is in table 3 . Blood $\mathrm{pH}$ differed

Ciência Rural, v.52, n.6, 2022. 
Table 2 - Mean values and standard deviations of the blood gas analyzes [blood $\mathrm{pH}$. blood bicarbonate concentration $\left(\mathrm{HCO}_{3}{ }^{-}-\mathrm{mmol}^{-} l\right)$, base excess $(\mathrm{BE}-\mathrm{mmol} / l)$, carbon dioxide partial pressure (pCO2 - mmHg)], glucose (GLUC - mg/d $l$ ), and lactate (LAC $\mathrm{mg} / \mathrm{d} l$ ) of foals hydrated with enteral electrolyte solutions containing different concentrations of acetate delivered in continuous flow by nasogastric route.

\begin{tabular}{|c|c|c|c|c|c|c|c|}
\hline \multirow[t]{3}{*}{ Variable } & \multirow[t]{3}{*}{ Groups } & \multicolumn{6}{|c|}{ 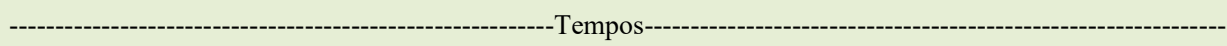 } \\
\hline & & \multirow{2}{*}{$\begin{array}{l}\text { Fasting } \\
\mathrm{T}-12 \mathrm{~h}\end{array}$} & \multicolumn{4}{|c|}{-----------------------------------Fluid Therapy--------------------------------- } & \multirow{2}{*}{$\begin{array}{c}\text { Clinical } \\
\text { Observation } \\
\mathrm{T} 24 \mathrm{~h}\end{array}$} \\
\hline & & & $\mathrm{T} 0 \mathrm{~h}$ & $\mathrm{~T} 4 \mathrm{~h}$ & $\mathrm{~T} 8 \mathrm{~h}$ & $\mathrm{~T} 12 \mathrm{~h}$ & \\
\hline \multirow[t]{2}{*}{$\mathrm{pH}$} & HighAcetate & $7.41 \pm 0 . .01^{\mathrm{Aab}}$ & $7 . .43 \pm 0 . .13^{\text {Aab }}$ & $7.41 \pm 0.03^{\mathrm{Ab}}$ & $7.43 \pm 0.02^{\mathrm{Aa}}$ & $7.42 \pm 0.02^{\text {Aab }}$ & $7.42 \pm 0.02^{\mathrm{Aab}}$ \\
\hline & LowAcetate & $7.41 \pm 0.02^{\mathrm{Ab}}$ & $7.43 \pm 0.01^{\mathrm{Aa}}$ & $7.39 \pm 0.02^{\mathrm{Abc}}$ & $7.39 \pm 0.02^{\mathrm{Bc}}$ & $7.39 \pm 0.01^{\mathrm{Bc}}$ & $7.41 \pm 0.02^{\mathrm{Abc}}$ \\
\hline \multirow{2}{*}{$\mathrm{HCO}_{3}^{-}$} & HighAcetate & $26.2 \pm 1.1^{\mathrm{b}}$ & $29.7 \pm 1.8^{\mathrm{a}}$ & $29.8 \pm 1.4^{\mathrm{a}}$ & $30.8 \pm 4.1^{\mathrm{a}}$ & $29.8 \pm 1.4^{\mathrm{a}}$ & $28.2 \pm 1.2^{\mathrm{a}}$ \\
\hline & LowAcetate & $24.7 \pm 0.8^{\mathrm{c}}$ & $29.8 \pm 1.5^{\mathrm{a}}$ & $27.6 \pm 1.7^{\mathrm{b}}$ & $27.5 \pm 1.9^{b}$ & $26.8 \pm 1.8^{\mathrm{bc}}$ & $27.5 \pm 0.8^{b}$ \\
\hline \multirow[t]{2}{*}{$\mathrm{BE}$} & HighAcetate & $1.37 \pm 0.93^{\mathrm{Ab}}$ & $4.50 \pm 1.66^{\mathrm{Aa}}$ & $4.20 \pm 1.32^{\mathrm{Aa}}$ & $4.45 \pm 1.65^{\mathrm{Aa}}$ & $4.43 \pm 1.48^{\mathrm{Aa}}$ & $3.07 \pm 1.22^{\mathrm{Ab}}$ \\
\hline & LowAcetate & $0.77 \pm 0.68^{\mathrm{Ac}}$ & $4.50 \pm 1.24^{\mathrm{Aa}}$ & $1.87 \pm 1.41^{\mathrm{Bb}}$ & $1.85 \pm 1.91^{\mathrm{Bbc}}$ & $1.43 \pm 1.59^{\mathrm{Bbc}}$ & $2.27 \pm 0.61^{\mathrm{Ab}}$ \\
\hline \multirow[t]{2}{*}{$\mathrm{pCO}_{2}$} & HighAcetate & $42.2 \pm 1.9^{c}$ & $45.7 \pm 1.8^{\mathrm{ab}}$ & $47.9 \pm 3.4^{\mathrm{a}}$ & $45.9 \pm 2.6^{\mathrm{ab}}$ & $46.5 \pm 1.5^{\mathrm{ab}}$ & $44.6 \pm 1.9^{\mathrm{bc}}$ \\
\hline & LowAcetate & $41.3 \pm 2.1^{b}$ & $46.1 \pm 2.0^{\mathrm{a}}$ & $46.9 \pm 3.2^{\mathrm{a}}$ & $46.6 \pm 1.7^{\mathrm{a}}$ & $45.1 \pm 2.8^{\mathrm{a}}$ & $44.7 \pm 2.3^{\mathrm{a}}$ \\
\hline \multirow[t]{2}{*}{ GLUC } & HighAcetate & $104 \pm 9.8^{b}$ & $94 \pm 7.2^{c}$ & $135 \pm 18.4^{\mathrm{a}}$ & $105 \pm 7.6^{\mathrm{bc}}$ & $129 \pm 12.9^{a}$ & $99 \pm 6.1^{\mathrm{bc}}$ \\
\hline & LowAcetate & $104 \pm 14.9^{\mathrm{ac}}$ & $97 \pm 3.9^{c}$ & $127 \pm 15.7^{\mathrm{a}}$ & $102 \pm 7.6^{\mathrm{bc}}$ & $119 \pm 13.7^{\mathrm{ab}}$ & $96 \pm 8.7^{c}$ \\
\hline \multirow[t]{2}{*}{ LAC } & HighAcetate & $9.8 \pm 1.7$ & $8.7 \pm 1.5$ & $6.6 \pm 1.5$ & $6.5 \pm 1.8$ & $6.7 \pm 0.8$ & $10 \pm 2.0$ \\
\hline & LowAcetate & $8.2 \pm 1.9$ & $7.7 \pm 1.4$ & $8.2 \pm 3.1$ & $6.6 \pm 2.5$ & $6.2 \pm 1.6$ & $10.2 \pm 2.6$ \\
\hline
\end{tabular}

ANOVA based on a factorial planning of repeated measures. Means followed by different superscripted lower-case letters on the same line differ between time-points by LSD test $(\mathrm{P}<0.05)$. Means followed by different superscripted upper-case letters in the same column indicate significant differences between treatments by LSD test $(\mathrm{P}<0.05)$.

between treatments and within treatments over time $(\mathrm{P}<0.05)$. A mild increase in blood $\mathrm{pH}$ after fasting (T0h) was observed in both treatments, but this change was statistically significant only for the LowAcetate group ( $\mathrm{P}<0.05)$. A higher blood $\mathrm{pH}$ was noted in the HighAcetate in comparison to the LowAcetate group during the fluid therapy phase (T0h to T12h), but this difference was significant $(\mathrm{P}<0.05)$ only at $\mathrm{T} 8 \mathrm{~h}$ and $\mathrm{T} 12 \mathrm{~h}$. A decrease in $\mathrm{pH}$ was observed in the LowAcetate group at $\mathrm{T} 4 \mathrm{~h}$, reaching the lowest values from $\mathrm{T} 8 \mathrm{~h}$ to $\mathrm{T} 12 \mathrm{~h}$.

In both groups blood bicarbonate concentration increased $(\mathrm{P}<0.05)$ after twelve hours of water and food restriction (T0h). During the fluid therapy phase ( $\mathrm{T} 0 \mathrm{~h}$ to $\mathrm{T} 12 \mathrm{~h}$ ) the concentration of blood bicarbonate was higher in the HighAcetate in comparison to the LowAcetate group, but these changes were not significant. A significant decrease in bicarbonate was observed in the LowAcetate group at T4h $(\mathrm{P}<0.05)$ and persisted until $\mathrm{T} 12 \mathrm{~h}$.

Base excess varied between treatments and within treatments over time $(\mathrm{P}<0.05)$. An increase in base excess was observed in both treatments at $\mathrm{T} 0 \mathrm{~h}(\mathrm{P}<0.05)$. The HighAcetate group showed significantly higher base excesses values in comparison to the LowAcetate group from $\mathrm{T} 4 \mathrm{~h}$ to $\mathrm{T} 12 \mathrm{~h}$. No significant changes in base excess were observed over time in the HighAcetate group during the fluid therapy phase (T0h to T12h). In the LowAcetate group base excess decreased progressively from $\mathrm{T} 4 \mathrm{~h}$ to $\mathrm{T} 12 \mathrm{~h}$, when the lowest value was observed. The $\mathrm{pCO}_{2}$ differed over time during the fluid therapy phase within groups $(\mathrm{P}<0.05)$ but did not differ between treatments. In both groups, an increase in $\mathrm{pCO}_{2}$ was observed at $\mathrm{T} 0 \mathrm{~h}$ and persisted until the end of the fluid therapy.

Blood glucose varied over time within groups $(\mathrm{P}<0.05)$ but no difference was observed between treatments $(\mathrm{P}>0.05)$. A significant decrease in blood glucose was observed at TOh only in the HighAcetate group $(\mathrm{P}<0.05)$. An increase in blood glucose was observed in both treatments during the fluid therapy phase at $\mathrm{T} 4 \mathrm{~h}$ and $\mathrm{T} 12 \mathrm{~h}$. The concentration of plasmatic L-lactate did not differ between treatments and within treatments over time $(\mathrm{P}>0.05)$.

A significant difference in urinary $\mathrm{pH}$ was noted over time and between treatments $(\mathrm{P}<0.05)$. An increase in urinary $\mathrm{pH}$ was observed in both treatment groups after food and water restriction (T0-2h). During the hydration phase (T0h-T12h) the HighAcetate group maintained the highest urinary $\mathrm{pH}$ values, which differed significantly from the LowAcetate group at $\mathrm{T} 2-6 \mathrm{~h}(\mathrm{P}<0.05)$. 
Table 3 - Mean values and standard deviations of urinary $\mathrm{pH}$ of foals hydrated with enteral electrolyte solutions containing different concentrations of acetate delivered in continuous flow by nasogastric route.

\begin{tabular}{|c|c|c|c|c|c|c|c|}
\hline \multirow[t]{3}{*}{ Variable } & \multirow[t]{3}{*}{ Groups } & & & ------------T & hes------------ & 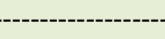 & \multirow{2}{*}{$\begin{array}{c}\text { Clinical } \\
\text { Observation }\end{array}$} \\
\hline & & \multirow{2}{*}{$\begin{array}{l}\text { Fasting } \\
\mathrm{T}-12 \mathrm{~h}\end{array}$} & ------------ & -.--Flui & Cherapy--- & "---' & \\
\hline & & & $\mathrm{T} 0-2 \mathrm{~h}$ & T2-6h & T6-10h & $\mathrm{T} 10-12 \mathrm{~h}$ & $\mathrm{~T} 24 \mathrm{~h}$ \\
\hline \multirow[b]{2}{*}{$\mathrm{pH}$} & HighAcetate & $6.88 \pm 0.99^{\mathrm{Aab}}$ & $7.64 \pm 0.47^{\mathrm{Aab}}$ & $7.50 \pm 0.32^{\mathrm{Ab}}$ & $7.43 \pm 0.17^{\mathrm{Ab}}$ & $7.53 \pm 0.14^{\mathrm{Ab}}$ & $8.04 \pm 0.24^{\mathrm{Aa}}$ \\
\hline & LowAcetate & $5.93 \pm 0.50^{\mathrm{Bb}}$ & $7.46 \pm 0.51^{\text {Aac }}$ & $6.93 \pm 0.06^{\mathrm{Bbc}}$ & $6.88 \pm 0.27^{\mathrm{Bc}}$ & $6.33 \pm 0.57^{\mathrm{Bb}}$ & $7.60 \pm 0.45^{\mathrm{Ba}}$ \\
\hline
\end{tabular}

ANOVA based on a factorial planning of repeated measures. Means followed by different superscripted lower-case letters on the same line differ between time-points by LSD test $(\mathrm{P}<0.05)$. Means followed by different superscripted upper-case letters in the same column indicate significant differences between treatments by LSD test $(\mathrm{P}<0.05)$.

\section{DISCUSSION}

At T0h both groups had an increase in blood $\mathrm{pH}$, but only the LowAcetate was statistically significant $(\mathrm{P}<0.05)$. At this same time $(\mathrm{T} 0 \mathrm{~h})$, the blood bicarbonate concentration and base excess increased in the two treatments $(\mathrm{P}<0.05)$. These results demonstrated that the period of food and water restriction had effects on the foals' acid-base balance. As described in an article complementary to this (MONTEIRO et al., 2020), fasting caused dehydration, hypernatremia, and relative hypochloremia in the foals of both treatments at $\mathrm{T} 0 \mathrm{~h}$. In response to relative hypochloremia, the kidneys conserve bicarbonate in order to maintain electroneutrality and mild alkalinemia can develop as a consequence (CONSTABLE, 2014; LUKE; GALLA, 2012). Those events can explain the slight increase in blood $\mathrm{pH}$ and mild alkalinemia observed at T0h, consistent with mild alkalosis due to chloride depletion (CONSTABLE, 2014). Although increased in both groups, blood bicarbonate and base excess levels remained in the reference range (27.2 to $31.2 \mathrm{mmol} / \mathrm{l}$ and 1.5 to $5.4 \mathrm{mmol} / \mathrm{l}$ respectively) (BROMMER; et al., 2001).

During the fluid therapy phase in both groups the blood $\mathrm{pH}$, blood bicarbonate concentration, and base excess stayed in the reference range (BROMMER; et al, 2001). But was difference between treatments in blood $\mathrm{pH}$ (at $\mathrm{T} 8 \mathrm{~h}$ and $\mathrm{T} 12 \mathrm{~h}$ ) and base excess (from T4h to T12h).

At the HighAcetate group, during the fluid therapy phase (T0h at T12h) the higher levels of blood $\mathrm{pH}$, blood bicarbonate concentration, and base excess can be associated with the greater acetate concentrations $(52 \mathrm{mmol} / \mathrm{l})$ in this treatment. It was enough to maintain slightly higher these parameters from T0h to the end of the fluid therapy (T12h), without worsening the alkalinemia triggered by the fasting period. In the LowAcetate group was a decrease in the blood $\mathrm{pH}$, blood bicarbonate concentration, and base excess starting $\mathrm{T} 4 \mathrm{~h}$, reaching its lowest level from $\mathrm{T} 8 \mathrm{~h}$ to $\mathrm{T} 12 \mathrm{~h}$, demonstrated the acetate concentration in LowAcetate treatment was not sufficient for maintaining the alkalinemia observed in T0h during the fluid therapy.

After absorption in the intestine, the acetate present in the enteral electrolyte solutions is metabolized by the liver and skeletal muscle, where it is converted to acetyl-CoA that enters the tricarboxylic cycle and respiratory chain resulting in the consumption of $\mathrm{H}^{+}$ions and consequent production of $\mathrm{H}_{2} \mathrm{O}$ and un-buffered $\mathrm{HCO}_{3}^{-}$, so it has an alkalinizing action without changing the $\mathrm{pH}$ of the intestinal lumen (KREBS, 1954; PATRA et al., 1982; SEN et al., 2009; WALLER\& LINDINGER, 2007; WALLER et al., 2009). The results of the present study agreed with WALLER \& LINDINGER (2007) and SEN et al. (2009) who observed in calves and adult horses, respectively, that sodium acetate is an efficient alkalinize agent that can be utilized in enteral electrolytes solutions alternatively to sodium bicarbonate.

The $\mathrm{pCO}_{2}$ represents the respiratory component in acid-base balance, by which the body regulates the acid concentration through gas exchange during breathing. When carbon dioxide is dissolved in water carbonic acid is formed, which dissociates in hydrogen ions and bicarbonate. When the $\mathrm{pCO}_{2}$ increases there is an accumulation of acid that causes a decrease in blood $\mathrm{pH}$ (CONSTABLE, 2000; DUNKEL\& CORLEY, 2015). In both treatments $\mathrm{pCO}_{2}$ increased after twelve hours of water and food restriction (TOh) as a compensatory response to generate hydrogen ions and compensate 
for the mild alkalemia observed at T0h. During the hydration phase ( $\mathrm{T} 0 \mathrm{~h}$ to $\mathrm{T} 12 \mathrm{~h}$ ) the $\mathrm{pCO}_{2}$ remained practically unchanged in both treatments (Table 2), demonstrating that both enteral electrolyte solutions stimulated this compensatory response. The increase in $\mathrm{pCO}_{2}$ prevented major variations in blood $\mathrm{pH}$ in both treatments; although, in the HighAcetate group it was not enough to prevent the mild increase in alkaline reserve observed.

The urinary $\mathrm{pH}$ reflects the acid-base balance in healthy animals because the kidneys are the first control mechanism for base or acid excretion (CONSTABLE, 2000). An increase in urinary $\mathrm{pH}$ was noted after water and food restriction (T0-2h) in both treatments $(\mathrm{P}<0.05)$ and reflects the mild alkalemia observed in the blood gas analysis at T0h. No changes in urinary $\mathrm{pH}$ were observed during the fluid therapy phase in the HighAcetate group. This finding is in agreement with blood gas findings and reflect the higher greater acetate metabolism with consequent greater acid buffering in the HighAcetate group. A significantly $(\mathrm{P}<0.05)$ lower urinary $\mathrm{pH}$ was observed in the LowAcetate group from T2-6h until T10-12h, when it reached values in the reference range for foals and similar to the start of the trial (T-12h) (EDWARDS; et al, 1990).

A mild decrease in blood glucose was noted in both treatment groups after food and water restriction, but the values remained in the reference range (83 to $126,5 \mathrm{mg} / \mathrm{dL}$ ) (MUÑOZ et al., 2012). An increase in blood glucose was observed during the fluid therapy phase (T4h to $\mathrm{T} 12 \mathrm{~h}$ ) and is a result of dextrose absorption from both electrolytic solutions. The hyperglycemia observed in both groups at $\mathrm{T} 4 \mathrm{~h}$ is a physiological process commonly observed in foals submitted to fasting and subsequently fed with dextrose (KRUSIC et al., 1997). Based on blood glucose findings and the observed glycemic curve, we can infer that the amount of dextrose present in both electrolyte solutions is adequate to maintain blood glucose levels during enteral fluid therapy in weaned foals. These findings are in contrast to adult horses, where $15 \mathrm{~g} / \mathrm{l}$ of dextrose caused hyperglycemia when added to enteral electrolyte solutions by RIBEIRO FILHO et al. (2014).

Plasma lactate concentrations remained unchanged throughout the experiment, showing that the concentration of carbohydrate in both solutions did not cause excessive fermentation in the gastrointestinal tract of foals. Similar results were observed in adult horses comparing the effects of the dextrose, maltodextrin, and sucrose in enteral electrolyte solutions (RIBEIRO FILHO et al., 2014).
One of the limitations of this study was that the $12 \mathrm{~h}$ of water and food restriction caused a mild metabolic alkalemia in the animals. The ideal model would be to evaluate the effects of these enteral electrolyte solutions on foals with metabolic acidosis. However, considering the welfare of the animals, it was decided not to induce this disorder in the foals of this study.

\section{CONCLUSION}

The $12 \mathrm{~h}$ of water and food restriction caused mild metabolic alkalemia and is therefore a safe experimental model for assessing acid base imbalances in foals. The HighAcetate treatment caused a slight increase in the alkaline reserve of the animals. These results open up new possibilities for the use of sodium acetate as an alkalinizing component in the enteral electrolyte solutions used for the treatment of metabolic acidosis in weaned foals.

\section{ACKNOWLEDGMENTS}

We are grateful to Coordenação de Aperfeiçoamento de Pessoal de Nível Superior - Brasil (CAPES) - Finance Code 001 by funding of this study.

DECLARATION OF CONFLICT OF
INTEREST

We have no conflict of interest to declare.

\section{AUTHORS' CONTRIBUTIONS}

All authors contributed equally for the conception and writing of the manuscript. All authors critically revised the manuscript and approved of the final version.

\section{BIOETHICS AND BIOSSECURITY COMMITTEE APPROVAL}

The animal care and use procedures were approved by Ethics Committee on the Use of Animals of the Universidade Federal de Viçosa (registration number 39/2018) and performed in according to the rules of the CONCEA.

\section{REFERENCES}

AVANZA, M. F. B. et al. Enteral fluid therapy in horses electrolyte solution associated or not with glucose, maltodextrine and magnesium sulphate: laboratory results.. Ciência Rural, v.39, n.4, p.1116-1123, 13 fev. 2009. Available from: <https://doi. org/10.1590/S0103-84782009005000021>. Accessed: Feb. 20, 2018. doi: 10.1590/S0103-84782009005000021.

BAHL, R.; et al.,. Reduced-osmolarity oral rehydration salts solution multicentre trial : Implications for national policy. Indian 
Journal of Pediatrics, v.63, n.4, p.473-476, 1996. Available from: <https://link.springer.com/article/10.1007/BF02905721>. Accessed: Mar. 23, 2018. doi: 10.1007/BF02905721

BROMMER, H.; et al., Haematology: Haematological and blood biochemical characteristics of Dutch warmblood foals managed under three different rearing conditions from birth to 5 months of age. Veterinary Quarterly, v.23, n.2, p.92-95, abr. 2001. Available from: <https://pubmed.ncbi.nlm.nih.gov/11361107/>. Accessed: Jun. 17, 2019. doi: 10.1080/01652176.2001.9695090.

CONSTABLE, P. D. Clinical assessment of acid-base status: Comparison of the Henderson-Hasselbalch and Strong Ion Approaches. Veterinary Clinical Pathology, v.29, n.4, p.115-128, 2000. Available from: $<$ https://doi.org/10.1111/j.1939-165X.2000 tb00241.x>. Accessed: Jun. 17, 2019. doi: 10.1111/j.1939165X.2000.tb00241.x.

CONSTABLE, P. D. Acid-base Assessment when and How To Apply the Henderson- Hasselbalch Equation and Strong Ion Difference Theory. Veterinary Clinics of NA: Food Animal Practice, v.30, n.2, p.295-316, 2014. Available from: <https:// pubmed.ncbi.nlm.nih.gov/24980723/>. Accessed: Jun. 17, 2019. doi: 10.1016/j.cvfa.2014.03.001.

DANTAS, W. M. F. et al. Hypotonic enteral electrolyte solutions administered by nasoesophageal tube in continuous flow in dogs dehydrated by water restriction: Part 1. Arquivo Brasileiro de Medicina Veterinária e Zootecnia, abr. 2019. v.71, n.2, p.404 410. Available from: <https://www.scielo.br/j/abmvz/a/bpMr93Z FhFz4jBcK3YMNftD/?lang=en>. Accessed: Jun. 17, 2019. doi: $10.1590 / 1678-4162-10459$.

DUNKEL, B.; CORLEY, K. T. T. Pathophysiology, diagnosis and treatment of neonatal sepsis. Equine Veterinary Education, v.27, n.2, p.92-98, 2015. Available from: <https://doi.org/10.1111/ eve.12234>. Accessed: Jan. 02, 2019. doi: 10.1111/eve.12234.

EDWARDS, D.; et al. Indices of renal function: values in eight normal foals from birth to 56 days. Australian Veterinary Journal, v.67, n.7, p.251-254, jul. 1990. Available from: <https:// pubmed.ncbi.nlm.nih.gov/2393372/>. Accessed: Jun. 18, 2019. doi: 10.1111/j.1751-0813.1990.tb07779.x.

ERMITA, P. A. N. et al. Effects of enteral Fluid Therapy in Continuous Flow Administered by Nasogastric Tube in Buffalo Calves. Journal of Buffalo Science, v.5, n.3, p.60-69, 13 dez. 2016. Available from: $<$ https://ifescienceglobal.com/pms/index. php/JBS/article/view/4270/0>. Accessed: Jan. 17, 2019. doi: 10.6000/1927-520X.2016.05.03.2.

ERMITA, P. A. N. et al. Enteral fluid therapy administered in continuous flow by naso-ruminal route using three maintenance electrolyte solutions: Effects on physiological biomarkers and the hemogram of bovines. Ciancia Rural, 2018. v.48, n.8, p.1-7. Available from: $<$ https://doi.org/10.1590/0103-8478cr20180217>. Accessed: Jan. 17, 2019. doi: 10.1590/0103-8478cr20180217.

GOMEZ, D. E. et al. Physicochemical interpretation of acid-base abnormalities in 54 adult horses with acute severe colitis and diarrhea. Journal of Veterinary Internal Medicine, v.27, n.3, p.548-553, 2013. Available from: $<$ https://pubmed.ncbi.nlm.nih.gov/23551698/>. Accessed: Jun. 17, 2019. doi: 10.1111/jvim. 12071.

GOMEZ, D. E.; et al. Physicochemical approach to Determine the Mechanism for Acid-Base Disorders in 793 Hospitalized Foals.
Journal of Veterinary Internal Medicine, v.29, n.5, p.13951402, set. 2015. Available from: <https://onlinelibrary.wiley. com/doi/full/10.1111/jvim.13590>. Accessed: Jun. 09, 2019. doi: 10.1111/jvim. 13590 .

KOTERBA, A. M.; et al. Clinical and clinicopathological characteristics of the septicaemic neonatal foal: Review of 38 cases. Equine Veterinary Journal, v.16, n.4, p.376-382, jul. 1984. Available from: <https://beva.onlinelibrary.wiley.com/doi/ abs/10.1111/j.2042-3306.1984.tb01950.x>. Accessed: Jul. 17, 2018. doi: 10.1111/j.2042-3306.1984.tb01950.x.

KREBS, H. A. The Tricarboxylic Acid Cycle. In: Chemical Pathways of Metabolism. 1. ed. New York : Elsevier, 1954. Cap.4, p.109-171.

KRUSIC, L. et al. Insulin response after oral glucose application in growing insulin response after oral glucose application in growing lipizzaner foals. Proceedings of the 15th Equine Nutrition and Physiology Symposium, p.397-403, 1997. Available from: <https://www.researchgate.net/publication/267974086 INSULIN RESPONSE AFTER ORAL GLUCOSE APPLICATION_IN_GROWWING_LIPIZZAN̄ citations>. Accessed: Jun. 17, 2019.

MARSHALL, T. S. et al. Effect of suckling an isotonic solution of sodium acetate, sodium bicarbonate, or sodium chloride on abomasal emptying rate and luminal $\mathrm{pH}$ in calves. American Journal of Veterinary Research, v.69, n.6, p.824-831, jun. 2008. Available from: <https://doi.org/10.2460/ajvr.69.6.824>. Accessed: Oct. 18, 2019. doi: 10.2460/ajvr.69.6.824.

MUÑOZ,A. et al. Age- and gender-related variations in hematology, clinical biochemistry, and hormones in Spanish fillies and colts. Research in Veterinary Science, v.93, n.2, p.943-949, out. 2012. Available from: <https://pubmed.ncbi.nlm.nih.gov/22230595/>. Accessed: May, 29, 2019. doi: 10.1016/j.rvsc.2011.11.009.

NAYLOR, J. M.; FORSYTH, G. W. The alkalinizing effects of metabolizable bases in the healthy calf. Canadian journal of veterinary research $=$ Revue canadienne de recherche veterinaire, v.50, n.4, p.509-516, 1986. Available from: <https:// www.ncbi.nlm.nih.gov/pmc/articles/PMC1255256/>. Accessed: May, 3, 2019. PMID: 3024796.

PATRA, F. C. et al. Can acetate replace bicarbonate in oral rehydration solution for infantile diarrhoea? Archives of Disease in Childhood, v.57, n.8, p.625-627, 1 ago. 1982. Available from: $<$ https://adc.bmj.com/content/57/8/625.short>. Accessed: Mar. 23, 2019. doi: 10.1136/adc.57.8.625.

PETHICK, D. W. et al. Nutrient utilization by the hindlimb of thoroughbred horses at rest. Equine Veterinary Journal, v.25, n.1, p.41-44, 1993. Available from: <https://pubmed.ncbi.nlm. nih.gov/8422883/>. Accessed: Jun. 17, 2019. doi: 10.1111/j.20423306.1993.tb02899.x.

RAUTANEN, T.; et al. Randomised double blind study of hypotonic oral rehydration solution in diarrhoea. Arch Dis Child, v.76, n.3, p.272-274, 1997. Available from: <https://pubmed.ncbi. nlm.nih.gov/9135272/>. Accessed: Jun. 14, 2019. doi: 10.1136/ adc. 76.3 .272 .

RIBEIRO FILHO, J. D. et al. Evaluation of isotonic electrolyte solution administered by enteral via in healthy cattle or dehydrated experimentally. Veterinária e Zootecnia, v.20, n.3, p.9-16, 2013. 
Available from: <https://doi.org/10.1590/0103-8478cr20160891>. Accessed: Jun. 17, 2019. doi: 10.1590/0103-8478cr20160891.

RIBEIRO FILHO, J. D. et al. Enteral fluid therapy: biochemical profile of horses treated with hypotonic enteral electrolyte solutions associated with energy sources. Journal of Equine Veterinary Science, v.34, n.6, p.759-764, jun. 2014. Available from: $\quad<$ https://www.sciencedirect.com/science/article/abs/pii/ S0737080614000057>. Accessed: Jun. 26, 2019. doi: 10.1016/j. jevs.2014.01.004.

RIBEIRO FILHO, J. D. et al. Enteral electrolyte solutions with different osmolarities administered in a continuous flow in newborn calves. Ciência Rural, v.47, n.5, p.1-6, 2017a. Available from: $<$ https://doi.org/10.1590/0103-8478cr20160891 >. Accessed: Jun. 23, 2019. doi: 10.1590/0103-8478cr20160891.

RIBEIRO FILHO, J. D. et al. Enteral fluid therapy in horses: effects of maintenance hypotonic electrolyte solutions containing maltodextrin, sucrose, or dextrose administered in continuous flow. Journal of Equine Veterinary Science, v.50, p.96101, mar. 2017b. Available from: <https://doi.org/10.1016/j. jevs.2016.11.007>. Accessed: Jun. 25, 2019. doi: 10.1016/j. jevs.2016.11.007.
SEN, I. et al. Efficacy of oral rehydration therapy solutions containing sodium bicarbonate or sodium acetate for treatment of calves with naturally acquired diarrhea, moderate dehydration, and strong ion acidosis. Journal of the American Veterinary Medical Association, v.234, n.7, p.926-934, abr. 2009. Available from: $<$ https://pubmed.ncbi.nlm.nih.gov/19335244/>. Accessed: Jul. 17, 2019. doi: 10.2460/javma.234.7.926.

WALLER, A.; LINDINGER, M. I. The effect of oral sodium acetate administration on plasma acetate concentration and acid-base state in horses. Acta Veterinaria Scandinavica, v.49, n.1, p.1-12, 2007. Available from: <https://pubmed.ncbi.nlm.nih.gov/18096070/>. Accessed: Jun. 25, 2019. doi: 10.1186/1751-0147-49-38.

WALLER, A. P. et al. Oral acetate supplementation after prolonged moderate intensity exercise enhances early muscle glycogen resynthesis in horses. Experimental Physiology, v.94, n.8, p.888-898, 1 ago. 2009. Available from: $<$ https://pubmed.ncbi.nlm.nih.gov/19429643/>. Accessed: Jun. 17, 2019. doi: 10.1113/expphysiol.2009.047068.

WORLD HEALTH ORGANIZATION. Oral Rehydration salts: Production of the new ORS. Geneva: World Health Organization, 2006. Available from: $<$ https://apps.who.int/iris/bitstream/handle/10665/69227/ WHO FCH CAH 06.1.pdf $>$. Accessed: Mar. 21, 2019. 